\title{
Genetic variation is predominantly structured by geography rather than host in feather mites (Acariformes: Sarcoptiformes) associated with tanagers (Aves: Thraupidae) in Brazil
}

\author{
Luiz Gustavo de A. Pedroso ${ }^{1=-(}$, Pavel B. Klimov ${ }^{2,3,4}$, Fabio A. Hernandes ${ }^{5 \oplus}$
}

${ }^{1}$ Departamento de Zoologia, Universidade Estadual Paulista (UNESP), Rio Claro, SP, Brazil. ${ }^{2}$ Department of Ecology and Evolutionary Biology, Museum of Zoology Research Museums Center, University of Michigan, Ann Arbor, Michigan, USA. ${ }^{3}$ Tyumen State University, Tyumen, Russia. ${ }^{4}$ Bangor University, School of Natural Sciences, Bangor, UK. ${ }^{5}$ Departamento de Ecologia e Zoologia, CCB/ECZ, Trindade, Universidade Federal de Santa Catarina, Florianópolis, SC, Brazil.

拝=Corresponding author: luizgustavopedroso@gmail.com

Edited by: Fernando de C. Jacinavicius (Guest Editor)

Received: November 05, 2021. Accepted: November 18, 2021. Published: December 08, 2021.

\begin{abstract}
Feather mites are the most common ectosymbionts on birds. These obligatory symbionts are mainly transmitted during their host's parental care, which creates high host specificity. Due to this intimate relationship, it is thought that their geographic distribution is restricted by their host distribution, or that a host species harbors the same mite composition across its whole range. However, our knowledge regarding the geographic distribution of feather mites remains scarce, with only a few studies indicating disconnections between mite and host distributions, especially in widespread hosts. Here, we investigate the feather mites distribution on four tanager species, three widespread - Thraupis sayaca (L.), T. palmarum (Wied), and Stilpnia cayana (L.) from Northern and Southern Brazil; and the Amazonian T. episcopus (L.). Feather mites were identified using the molecular barcode marker COX-1 using K2P genetic distances. We found a strong genetic structure between Northern and Southern populations of tanagers of more than $10 \%$, even among conspecific hosts. Therefore, the mite distribution on Brazilian tanagers is predominantly shaped by geography rather than by host species. These features in turn reflect historical horizontal transmissions among the hosts, suggesting a high potential for frequent host switches in these symbionts.
\end{abstract}

Keywords: cryptic species, biogeography, symbionts, coevolution, Psoroptidia.

Analgoidean feather mites (Sarcoptiformes: Analgoidea) are the most abundant ectosymbionts associated with passerine birds (Aves: Passeriformes) (Gaud \& Atyeo 1996). These mites have high levels of host specificity and most mite species are found on a single or closely related host species. In addition, different mites species can co-exist in different microhabitats of the same host individual (Dabert \& Mironov 1999). Despite being common and abundant avian ectosymbionts, many aspects of the feather mite ecology remain underexplored. One such aspect is their geographic distribution with respect to their host ranges. Does a feather mite distribution mirror that of its host? Does a host species have the same set of feather mites across its whole distribution? Only a few studies addressed those questions; in general they indicate that the feather mite assemblage on a bird species may be affected by climatic variables, such as humidity and temperature (Grossi \& Proctor 2021; Meléndez et al. 2014); or reflect vicariance due to historical isolation of host populations (Dabert \& Mironov 1999).

In ubiquitous hosts spread by humans, such as rock pigeons, Columba livia Gmelin, 1789 and domestic chickens, Gallus gallus domesticus (L., 1758), mite assemblages apparently change in new localities, indicating that some mite species have been acquired in recent events of interaction with native and phylogenetically similar host species (Gaud 1992). As for feather mites on naturally widespread host species, i.e. generalist hosts with high adaptive plasticity, a molecular identification of mites is often required to investigate their patterns of distribution, either for a proper identification of different mite haplotypes across different localities, as for the identification of potential cryptic species (Doña et al. 2015). Notwithstanding, assessing the geographic distribution of symbionts is a background needed to measure their dispersal potential and their specificity level. Yet, almost no effort has been made to properly understand the patterns of distribution of these symbionts, especially in the Neotropics, where many feather mite species are yet to be named (Valim et al. 2011; Pedroso \& Hernandes 2016). Our knowledge is especially scarce for Brazil, a country with various landscapes and one of the richest bird faunas in the World (Pacheco et al. 2021). Therefore, here we investigate the preliminary distribution of feather mites on tanagers (Thraupidae Cabanis, 1847), comparing samples from Brazilian Northern and Southern territories.

Feather mites were collected from four common and widespread tanager species: Thraupis sayaca (L., 1766), T. palmarum (Wied, 1821), Stilpnia cayana (L., 1766) from both Northern and Southern territories of Brazil, and the Amazonian T. episcopus (L., 1766). Birds were captured using mist nets in: Amazon Forest (AMF), Northeast Atlantic Forest (NAF), and Southeast Atlantic Forest (SAF) (Tab. 1). Feather mites were collected by plucking infested feathers (permit MMA/SISBIO 57944), then their DNA was extracted and a barcode gene, the mitochondrial cytochrome oxidase subunit-1 (COX-1) was sequenced following the protocols, primers, and parameters described in Klimov \& OConnor (2008). A Maximum Likelihood phylogenetic tree was inferred using RaxML, also using sequences from previous studies, including samples of mites on tanagers from Mexico (Klimov et al. 2017). Mite's exoskeletons (vouchers) were slide-mounted for morphological identification using Hoyer's Medium (Gaud \& Atyeo 1996). All specimens were deposited at the Department of Ecology and Zoology of the Universidade Federal de Santa Catarina (ECZ-UFSC).

Two species delimitation criteria based on the COX-1 were also performed - (i) a distance based delimitation using the Kimura-twoparameter (K2P) distance calculated in the R package 'ape' 5.3 (Paradis 
Table 1. Detailed information on each feather mite species, host species, collection codes, sampling sites, and GenBank accession numbers used in the present study.

\begin{tabular}{|c|c|c|c|c|c|c|}
\hline Mite Haplotype & Host Species & Mite Code & Host Code & Location & Coordinates & GenBank Codes \\
\hline Trouessartia sp. & Thraupis sayaca & LGAP77 & SP53 & Rio Claro, SP & $22^{\circ} 23^{\prime} 46.4^{\prime \prime} \mathrm{S} 47^{\circ} 32^{\prime} 50.1^{\prime \prime} \mathrm{W}$ & MW814607 \\
\hline Trouessartia sp. & Thraupis sayaca & LGAP78 & PE07 & Recife, PE & $8^{\circ} 03^{\prime} 09.7^{\prime \prime S} 34^{\circ} 57^{\prime} 07.1^{\prime \prime} \mathrm{W}$ & MW814608 \\
\hline Trouessartia sp. & Thraupis palmarum & LGAP79 & AC08 & Rio Branco, $\mathrm{AC}$ & $9^{\circ} 37^{\prime} 23.2^{\prime \prime} \mathrm{S} 67^{\circ} 35^{\prime} 33.1^{\prime \prime} \mathrm{W}$ & MW814609 \\
\hline Trouessartia sp. & Thraupis palmarum & LGAP80 & RN17 & Natal, RN & $5^{\circ} 50^{\prime} 33.5^{\prime \prime} \mathrm{S} 35^{\circ} 12^{\prime} 05.6^{\prime \prime} \mathrm{W}$ & MW814610 \\
\hline Trouessartia sp. & Thraupis episcopus & LGAP81 & PA06 & Belem, PA & $1^{\circ} 27^{\prime} 03.8^{\prime \prime} \mathrm{S} 48^{\circ} 26^{\prime} 40.1^{\prime \prime} \mathrm{W}$ & MW814611 \\
\hline Proctophyllodes sp. & Stilpnia cayana & LGAP101 & SP10 & Rio Claro, SP & $22^{\circ} 23^{\prime} 46.4^{\prime \prime} \mathrm{S} 47^{\circ} 32^{\prime} 50.1^{\prime \prime} \mathrm{W}$ & MW814629 \\
\hline Proctophyllodes sp. & Stilpnia cayana & LGAP102 & RN22 & Natal, RN & $5^{\circ} 50^{\prime} 33.5^{\prime \prime} \mathrm{S} 35^{\circ} 12^{\prime} 05.6^{\prime \prime} \mathrm{W}$ & MW814630 \\
\hline Proctophyllodes sp. & Stilpnia cayana & LGAP103 & PE03 & Recife, PE & $8^{\circ} 03^{\prime} 09.7^{\prime \prime S} 34^{\circ} 57^{\prime} 07.1^{\prime \prime} \mathrm{W}$ & MW814631 \\
\hline Proctophyllodes cf. thraupis & Thraupis sayaca & LGAP104 & SP22 & Rio Claro, SP & $22^{\circ} 23^{\prime} 46.4^{\prime \prime} \mathrm{S} 47^{\circ} 32^{\prime} 50.1^{\prime \prime} \mathrm{W}$ & MW814632 \\
\hline Proctophyllodes cf. thraupis & Thraupis sayaca & LGAP105 & RN20 & Natal, RN & $5^{\circ} 50^{\prime} 33.5^{\prime \prime} \mathrm{S} 35^{\circ} 12^{\prime} 05.6^{\prime \prime} \mathrm{W}$ & MW814633 \\
\hline Proctophyllodes cf. thraupis & Thraupis palmarum & LGAP107 & $\mathrm{ACO} 7$ & Rio Branco, AC & $9^{\circ} 57^{\prime} 00.0^{\prime \prime} \mathrm{S} 67^{\circ} 44^{\prime} 00.0^{\prime \prime} \mathrm{W}$ & MW814636 \\
\hline Proctophyllodes cf. thraupis & Thraupis palmarum & LGAP108 & RN17 & Natal, RN & $5^{\circ} 50^{\prime} 33.5^{\prime \prime} \mathrm{S} 35^{\circ} 12^{\prime} 05.6^{\prime \prime} \mathrm{W}$ & MW814637 \\
\hline
\end{tabular}

\& Schliep 2019), and (ii) a barcoding gap analysis, using the Automatic Barcode Gap Discovery (ABGD), which groups putative species based on the barcoding gap among samples (Puillandre et al. 2012).

We recorded three feather mite lineages showing cases of geographic partitioning with large genetic distances on tanagers in Brazil, one representing the mite genus Trouessartia Canestrini, 1899, and two other lineages in the mite genus Proctophyllodes Robin, 1868 (Fig. 1A, B, C). The mite lineages presented similar patterns of geographic distribution, defined by the separation of mite populations between birds from Northern and Southern territories in Brazil. Trouessartia species yielded a genetic distance higher than $12 \%$ between the NAF and AMF vs. SAF host populations (Fig. 1A; 2A). In Proctophyllodes, one lineage (Proctophyllodes thraupis Atyeo \& Braasch, 1966, described from Thraupis abbas (Deppe, 1830)), had genetic distance above $10 \%$ between AMF vs. NAF and SAF (Fig. 1B; 2B); while the other lineage, which included solely mites from Stilpnia cayana, had genetic distances above $12 \%$ between NAF vs. SAF populations (Fig. 1C; 2 C).

Both species delimitation methods ( $A B G D$ and K2P) inferred to a split in the mite populations on tanagers in Brazil following a geographic pattern. The distribution pattern differed among the mite lineages, as both the Trouessartia and Proctophyllodes lineages from S. cayana presented a clear division between samples from Southern territories (SAF) from samples from Northern territories (NAF and AMF) (Fig. 1A, C; $2 \mathrm{~A}, \mathrm{C}$ ). A different pattern of distribution was observed for the $P$. thraupis lineage, where the mite populations in the Atlantic Forest (SAF and NAF) presented connections between them, while the mite population from Amazon composed a separate group (Fig. 1B; 2B).

This pattern of distribution where the Northern Atlantic Forest is
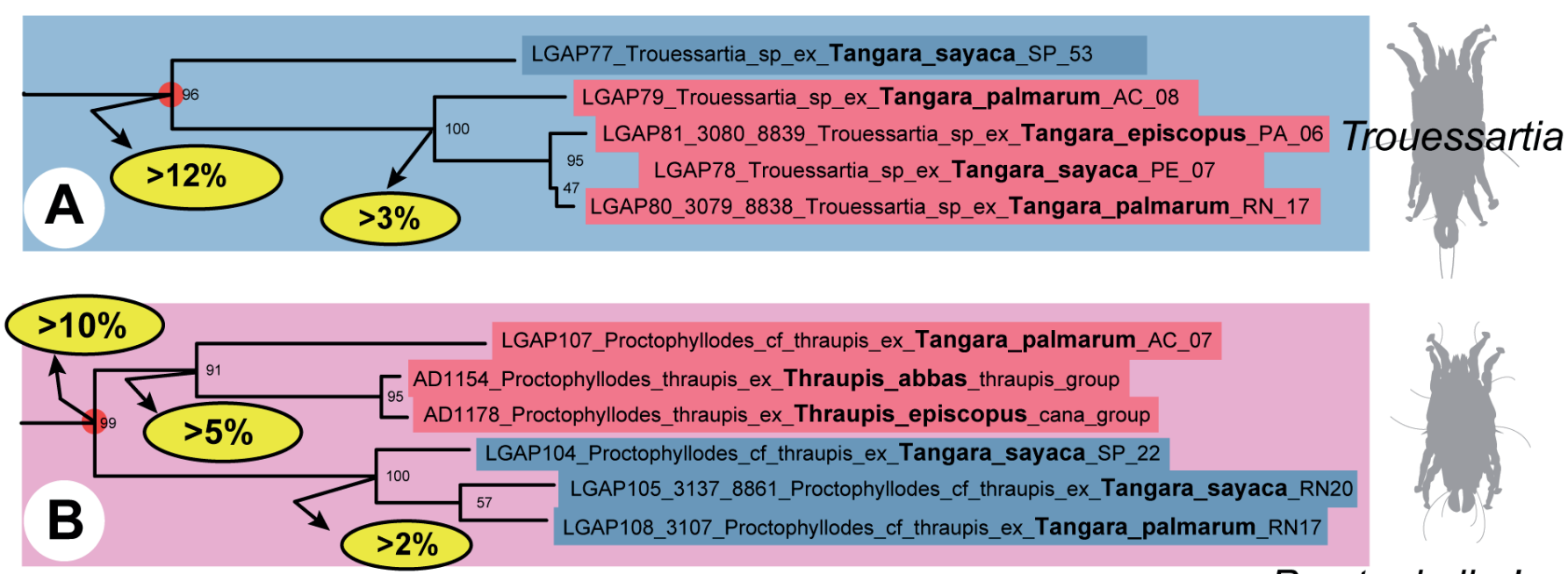

Proctophyllodes

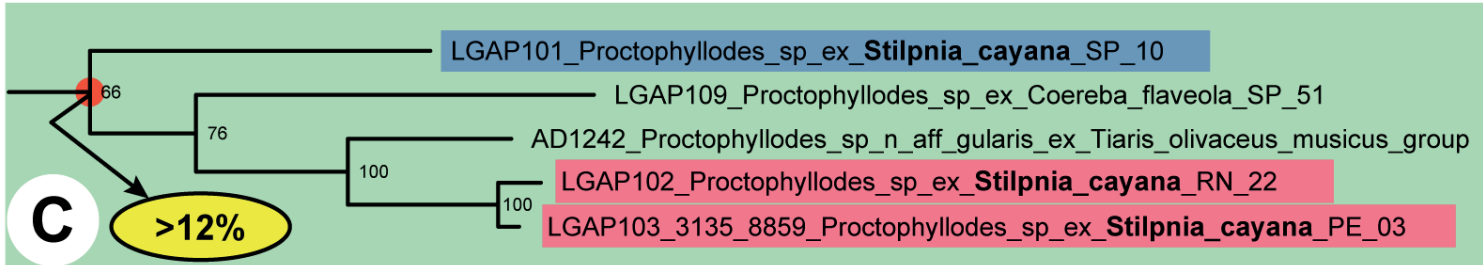

Northern samples

Southern samples
K2P genetic distance (\%)

Relevant divergence nodes
Trouessartia lineage

Proctophyllodes lineage

Figure 1. Genetic distance of three feather mite lineages - one Trouessartia (A) and two Proctopyllodes (B and C) on tanagers in Brazil. The relevant diverging nodes have their genetic distances in percentage highlighted. The relevant taxa were highlighted according to their sampling location: Northern and Southern territories. 
more related to the Amazon Forest than with the Southern Atlantic Forest has been recorded in other taxa (Santos et al. 2007; SobralSouza et al. 2015; Thomé et al. 2016; Ledo \& Colli 2017) including birds (Batalha-Filho et al. 2013). Many studies suggest that the "dry diagonal" formed by the biomes Chaco, Cerrado, and Caatinga, is an important barrier preventing biotic exchange between the rain forests (Amazon and Atlantic Forest) (Werneck et al. 2011). Our data corroborate these biogeographic hypotheses and give valuable evidences for obligate symbionts in this regard. A similar allopatric pattern of feather mites were recorded in Europe, where different species of the mite genus Scutulanyssus Mironov, 1985 (Analgoidea: Pteronyssidae) were identified occurring on populations of the House Martin, Delichon urbicum (L., 1758), separated by the Ural Mountains (Dabert \& Mironov 1999; Dabert 2004). In that study, however, the morphological differentiation of the mite species was evident, while in our study this pattern could be detected by using molecular data only.

The smallest genetic distance between samples from different territories was found in the $P$. thraupis clade, where mites from AMF differed in at least $10 \%$ with Atlantic Forest mites (SAF and NAF). This COX-1 genetic variation was expressively above the threshold of $3.4 \%$ found for species delimitation of feather mites in European passerines (Doña et al. 2015). Yet, in these European passerines, no genetic structure among mites collected from different geographic territories and different host species was found, and instead, putative cryptic species for feather mites on close related hosts were recognized (Doña et al. 2015). In North America, a minimum COX-1 distance of $6.6 \%$ among proctophyllodid species was identified on parulid warblers, with mites phylogenetically related according to their host's nesting ecology (Matthews et al. 2018). In our study, the distribution of feather mites among tanagers were geographically shaped instead of following a host-specific pattern of distribution, i.e. close related mites were recorded on different host species instead among conspecific hosts, reflecting the relevance of horizontal pathways for their dispersion. Quantitative and thorough morphological analyses are needed to see if there are any morphological discontinuities in the cryptic species detected by molecular methods. Further studies, increasing the sample size and geographic coverage, are necessary to properly understand the pattern of genetic distribution of feather mites observed on Brazilian tanagers.
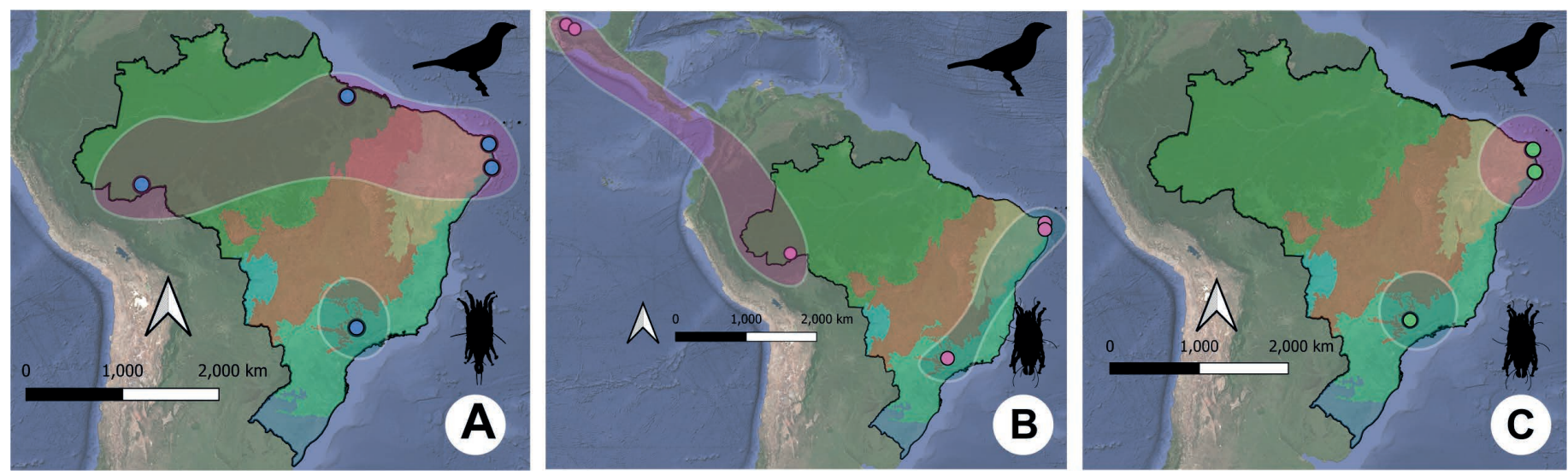

Figure 2. Schematic representation of geographic partition observed in different lineages of feather mites on tanagers in Brazil. A - Trouessartia on Thraupis, B Proctophyllodes on Thraupis, and C - Proctophyllodes on Stilpinia. Phylogeographic clusters are represented.

\section{Acknowledgements}

We thank the following people who helped organizing field trips - Dr. Gerturd Müller (UFPel), Dr. Fabiana F. Bernardon (UFPel), Dr. Lilian Manica (UFPR), Dr. Luiz dos Anjos (UEL), Dr. Edson Guilherme da Silva (UFAC), Dr. Mauro Pichorim (UFRN), Dr. Luciano Naka (UFPE), Dr. Roberto Cavalcanti (UNB), Dr. Sérgio Posso (UFMS), and Dr. Marco A. Pizo (UNESP-RC). LGAP was funded by São Paulo Research Foundation (FAPESP, 2018/21504-0 and 2016/11671-1). PBK was supported by the Russian Science Foundation (RNF), grant No. 19-14-00004. FAH was supported by the National Council for Scientific and Technological Development (CNPq-Brazil Researcher, 304479/2019-5).

\section{Authors' Contributions}

LGAP collected the mite samples and wrote the first draft of the manuscript. Molecular work and analysis was done by L.G.A.P. and P.B.K. at the University of Michigan Museum of Zoology. PBK and FAH critically reviewed the final version of the manuscript.

\section{References}

Batalha-Filho, H.; Fjeldså, J.; Fabre, P.-H.; Miyaki, C. Y. (2013) Connections between the Atlantic and the Amazonian forest avifaunas represent distinct historical events. Journal of Ornithology, 154: 41-50. doi: 10.1007/s10336-012-0866-7

Dabert, J. (2004) Feather mites (Astigmata; Pterolichoidea, Analgoidea) and birds as models for cophylogenetic studies. Phytophaga, 14 409-424.

Dabert, J.; Mironov, S. V. (1999) Origin and evolution of feather mites.
Experimental and Applied Acarology, 23: 437-454.

Doña, J.; Diaz-Real, J.; Mironov, S.; Bazaga, P.; Serrano, D.; Jovani, R. (2015) DNA barcoding and minibarcoding as a powerful tool for feather mite studies. Molecular Ecology Resources, 15: 1216-1225. doi: 10.1111/1755-0998.12384

Gaud, J. (1992) Acquisition d'hotes nouveaux par les Acariens plumicoles. Bulletin de la Société Française de Parasitologie, 10: 79-91.

Gaud, J.; Atyeo, W. T. (1996) Feather mites of the world (Acarina, Astigmata): The supraspecific taxa - Part I (text). Annales du Musée Royal de l'Afrique Centrale, Sciences Zoologiques, 277: 1-193.

Grossi, A.; Proctor, H. (2021) Variation in ectosymbiont assemblages associated with rock pigeons (Columba livia) from coast to coast in Canada. Diversity, 13: 1-18. doi: 10.3390/d13010009

Klimov, P .B.; Mironov, S. V.; OConnor, B. M. (2017) Detecting ancient codispersals and host shifts by double dating of host and parasite phylogenies: Application in proctophyllodid feather mites associated with passerine birds. Evolution, 71: 2381-2397. doi: 10.1111/evo.13309

Klimov, P. B.; OConnor, B. M. (2008) Origin and higher-level relationships of psoroptidian mites (Acari: Astigmata: Psoroptidia): Evidence from three nuclear genes. Molecular Phylogenetics and Evolution, 47: 1135-1156. doi: 10.1016/j.ympev.2007.12.025

Ledo, R. M. D.; Colli, G. R. (2017) The historical connections between the Amazon and the Atlantic Forest revisited. Journal of Biogeography, 44: 2551-2563. doi: 10.1111/jbi.13049

Matthews, A. E.; Klimov, P. B.; Proctor, H. C.; Dowling, A. P. G.; Diener, L.; Hager, S. B.; Larkin, J. L.; Raybuck, D. W.; Fiss, C. J.; McNeil, D. J.; Boves, T. J. (2018) Cophylogenetic assessment of New World warblers (Parulidae) and their symbiotic feather mites (Proctophyllodidae). 
Journal of Avian Biology, 49: 1-17. doi: 10.1111/jav.01580

Meléndez, L.; Laiolo, P.; Mironov, S.; García, M.; Magaña, O.; Jovani, R. (2014) Climate-driven variation in the intensity of a host-symbiont animal interaction along a broad elevation gradient. PLoS One, 9: 1-11. doi: 10.1371/journal.pone.0101942

Pacheco, J. F.; Silveira, L. F.; Aleixo, A.; Agne, C. E.; Bencke, G. A.; Bravo, G.A.; Brito, G. R. R.; Cohn-Haft, M.; Maurício, G. N.; Naka, L. N., et al. (2021) Annotated checklist of the birds of Brazil by the Brazilian Ornithological Records Committee-second edition. Ornithology Research, 29: 94-105. doi: 10.1007/s43388-021-00058-x

Paradis, E.; Schliep, K. (2019) Ape 5.0: An environment for modern phylogenetics and evolutionary analyses in R. Bioinformatics, 35: 526-528. doi: 10.1093/bioinformatics/bty633

Pedroso, L. G. A.; Hernandes, F. A. (2016) New records of feather mites (Acariformes: Astigmata) from non-passerine birds (Aves) in Brazil. Check List, 12: doi: 10.15560/12.6.2000

Puillandre, N.; Lambert, A.; Brouillet, S.; Achaz, G. (2012) ABGD, Automatic Barcode Gap Discovery for primary species delimitation. Molecular Ecology, 21: 1864-1877. doi: 10.1111/j.1365294X.2011.05239.x

Santos, A. M. M.; Cavalcanti, D. R.; Da Silva, J. M. C.; Tabarelli, M. (2007) Biogeographical relationships among tropical forests in north-eastern Brazil. Journal of Biogeography, 34: 437-446. doi: 10.1111/j.1365-2699.2006.01604.x

Sobral-Souza, T.; Lima-Ribeiro, M. S.; Solferini, V. N. (2015) Biogeography of Neotropical Rainforests: past connections between Amazon and Atlantic Forest detected by ecological niche modeling. Evolutionary Ecology, 29: 643-655. doi: 10.1007/s10682-015-9780-9

Thomé, M. T. C.; Sequeira, F.; Brusquetti, F.; Carstens, B.; Haddad, C. F. B.; Rodrigues, M. T.; Alexandrino, J. (2016) Recurrent connections between Amazon and Atlantic forests shaped diversity in Caatinga four-eyed frogs. Journal of Biogeography, 43: 1045-1056. doi: 10.1111/jbi.12685

Valim, M. P.; Hernandes, F. A.; Proctor, H. C. (2011) Feather mites of Brazil (Acari: Astigmata: Analgoidea and Pterolichoidea). International Journal of Acarology, 37: 293-324. doi: 10.1080/01647954.2010.519719

Werneck, F. P.; Costa, G. C.; Colli, G. R.; Prado, D. E.; Sites Jr, J. W. (2011) Revisiting the historical distribution of Seasonally Dry Tropical Forests: new insights based on palaeodistribution modelling and palynological evidencegeb. Global Ecology and Biogeography, 20: 272-288. doi: 10.1111/j.1466-8238.2010.00596.x 